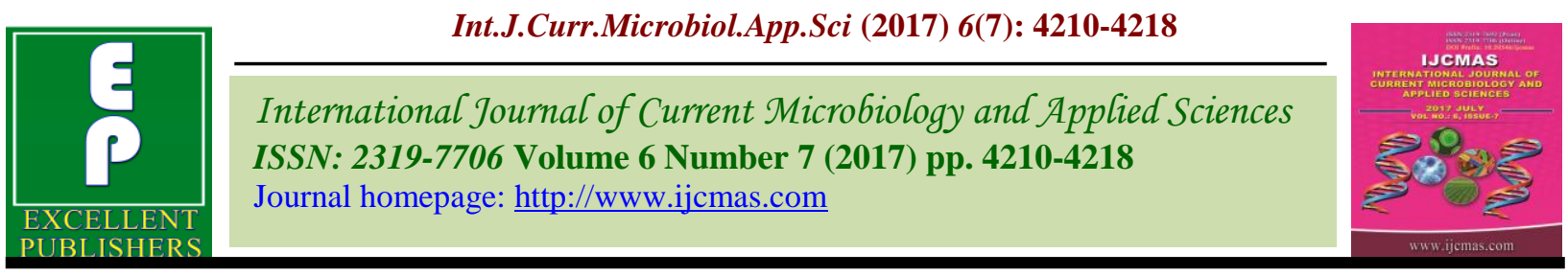

Original Research Article

https://doi.org/10.20546/ijcmas.2017.607.436

\title{
Combined Effect of Edible Coatings and Low Temperature on Plum Fruit Quality
}

\author{
Pushpendra Kumar, Shruti Sethi* and R.R. Sharma \\ Division of Food Science and Postharvest Technology, ICAR-Indian Agricultural Research \\ Institute, New Delhi - 110 012, India \\ *Corresponding author
}

\begin{tabular}{|c|c|}
\hline & A B S T R A C T \\
\hline Keywords & \multirow{4}{*}{$\begin{array}{l}\text { In this study, plums were coated with lac based (2:3), Semperfresh }{ }^{\mathrm{TM}}(1: 3) \text {, vegetable } \\
\text { wax (1:5) and water dip (control) just after harvest on field as on-farm treatment and } \\
\text { after transportation to the lab as off-farm treatment. After coating, the fruits were } \\
\text { packed in punnets and stored under cold storage conditions }\left(2 \pm 1{ }^{\circ} \mathrm{C}\right) \text { at } 90-92 \% \\
\text { relative humidity. The effectiveness of the edible coatings was evaluated by the } \\
\text { changes of several attributes: soluble solids content, titratable acidity, total phenols, } \\
\text { ascorbic acid content, pectin methylesterase activity (PME) and malondialdehyde } \\
\text { content (MDA). The coatings, especially the lac based coating significantly decrease } \\
\text { the changes in biochemical parameters and maintaining overall fruit quality of plums } \\
\text { followed by Semperfresh }{ }^{\mathrm{TM}} \text { and vegetable wax coatings. Therefore, the On-farm } \\
\text { application of edible coatings especially, lac based coating could be favourable in } \\
\text { maintaining quality and extending shelf-life of 'Santa Rosa' plum upto } 35 \text { days. }\end{array}$} \\
\hline $\begin{array}{l}\text { Plum, Edible } \\
\text { coating, Semper } \\
\text { fresh TM, } \\
\text { Vegetable wax, } \\
\text { Lac based, } \\
\text { Quality, Shelf life. }\end{array}$ & \\
\hline Article Info & \\
\hline $\begin{array}{l}\text { Accepted: } \\
\text { 29 June } 2017 \\
\text { Available Online: } \\
\text { 10 July } 2017\end{array}$ & \\
\hline
\end{tabular}

\section{Introduction}

The plum fruits are very appreciated by the consumers, the degree of acceptance depends on its organoleptic properties like firmness, colour, aroma and flavour which are vary production areas and from season to season and among cultivars (Crisosto et al., 2004). The plum fruit are a very rich source of antioxidant compounds such as ascorbic acid, carotenoids, anthocyanins and polyphenols, so that it has a beneficial health effects (Cevallos- Casals et al., 2006; Díaz-Mula et al., 2008; Vizzotto et al., 2007). The low temperature during storage is essential for plum fruit due to its perishable nature to decrease changes such as respiration rate, ethylene production, and loss of weight, reduction in acidity, tissue softening and pigment changes (Díaz-Mula et al., 2009; Guerra and Casquero, 2008). The transportation, marketing and storage of plums are a very serious problem due to its perishable nature. In India, fruits of plum are transported to plains for marketing from farflung areas located in different terrains and at high altitudes. Consequences, shelf-life of plums are further reduced drastically due to improper handling and lack of proper storage conditions which limits the availability of the plums. Thus, cold storage is an effective and most commercially practiced technology for increasing shelf life of plum fruits. However, cold storage is not sufficient to preserve the 
quality of plum fruits at optimum levels during transportation, storage and marketing, often leading to severe chilling injury. Appropriate postharvest technologies combined with low temperature storage are required. In this regard, various treatments prior to low temperature storage, such as heat, polyamines, calcium and 1-MCP (Valero and Serrano, 2010) as well as the use of modified atmosphere packaging (MAP) (Díaz-Mula et al., 2011) have been reported to preserve quality of plum fruits for a longer periods than cold storage alone.

On the other hand, the use of edible coatings are very effective to maintain fruit quality by reducing gas exchange, moisture, respiration, solute migration and the oxidative reaction rates as well as by controlling physiological disorders (Baldwin et al., 1996) with additional advantage of reducing the volume of non-biodegradable packaging materials (Campos et al., 2011; Olivas et al., 2008).

Destruction of the natural wax coating during handling of the plum fruits and development of chilling injury symptoms at low temperature $\left(0-10^{\circ} \mathrm{C}\right)$ storage conditions have been observed. Thus, the Considering the existing problems and practical importance of the work, the present study was carried out to study and compare the effects of on-farm and off-farm application of edible coatings, namely, Semperfresh ${ }^{\mathrm{TM}}$, vegetable wax and lac based on shelf life and quality of 'Santa Rosa' plums during storage at $2 \pm 1{ }^{\circ} \mathrm{C}$.

\section{Materials and Methods}

\section{Plant material, treatment and storage conditions}

The plums of 'Santa Rosa' variety were harvested at climacteric stage of maturity from a private orchard at Kullu (Himachal Pradesh, India). One set of plum fruits (containing $10 \mathrm{~kg}$ ) was subjected to application of different surface coatings, namely, Semperfresh ${ }^{\mathrm{TM}}(1: 3)$, vegetable wax (1:5), lac based (2:3) and control (distilled water dip) on the farm, air-dried for $1 \mathrm{~h}$ and then transported to the laboratory at New Delhi. The coated plums were packed in punnets having holes for ventilation and stored at $2 \pm 1^{\circ} \mathrm{C}$, for further study. The other set of freshly harvested plums were transported to the laboratory at Delhi) and treated similarly with edible coatings, airdried for $1 \mathrm{~h}$ and then packed in punnets followed by storage at $2 \pm 1^{\circ} \mathrm{C}$, for further study.

\section{Analysis of physiological and biochemical properties of fruits}

Estimation of total soluble solids and titratable acidity

Total soluble solids content of plums was estimated using Fisher hand refractometer ( 0 $\left.50^{\circ} \mathrm{B}\right)$ and expressed as degree Brix $\left({ }^{\circ} \mathrm{B}\right)$ at $20^{\circ} \mathrm{C}$. The titratable acidity of plums was estimated by titration with $0.1 \mathrm{~N}$, sodium hydroxide (Rangana, 1999).

\section{Measurements of total phenol and ascorbic acid}

Total phenol content of the plum fruits were measured by Folin-Ciocalteu reagent method and expressed as milligram gallic acid equivalent $100^{-1} \mathrm{~g}$. Determination of ascorbic acid content was done by a titration method using 2, 6 dichlorophenol indophenol dye (Rangana, 1999) and expressed as milligram $100 \mathrm{~g}^{-1}$.

\section{Measurement of enzyme activity}

PME activity in samples was determined by the method of Hagerman and Austin (1986). Five g. of fruit sample were homogenised in $15 \mathrm{~mL}$ ice cold $\left(4^{\circ} \mathrm{C}\right) 8.8 \%$ sodium chloride 
using pestle and mortar and centrifuged at $15,000 \mathrm{~g}$ for $15 \mathrm{~min}$. At $620 \mathrm{~nm}$ absorbance of the enzyme mixture was measured. The PME activity was expressed as $\mu \mathrm{mol} \mathrm{g}{ }^{-1} \mathrm{~min}^{-1}$ fresh fruit weight.

\section{Determination of malondialdehyde (MDA) content}

The malondialdehyde (MDA) content was measured using thiobarbituric acid by the method of Eum et al., (2009). Approximately two gram of plum sample was homogenized in ice-cold $0.2 \mathrm{M}$ phosphate buffer and centrifuged at $4^{\circ} \mathrm{C}$ for 15 minute at $5,000 \mathrm{~g}$. After homogenization aliquots collected and $1 \mathrm{ml}$ supernatant was used for malondialdehyde determination. Absorbance at 440, 532, and $600 \mathrm{~nm}$ was recorded using a spectrophotometer and the malondialdehyde content was expressed as $\mu \mathrm{mol} \mathrm{g}^{-1}$.

\section{Statistical analysis}

Two way analysis of variance was performed on the data sets using SAS 9.3 software and significant effects $(\mathrm{P}<0.05)$ were noted. Significant difference amongst the means was determined by Tukey's HSD.

\section{Results and Discussion}

\section{Total soluble solids and titratable acidity} content

The data presented in table 1 reveals that total soluble solids were significantly lower in untreated plums at both treatment sites than those treated with different edible coatings except Semperfresh ${ }^{\mathrm{TM}}$ coated. Control (water dipped) fruits of plum cv. 'Santa Rosa' showed an increase of TSS upto 21 day which later declined. In general, samples treated onfarm showed a higher retention of TSS in comparison to those treated off-farm. As against control (water dipped) fruits, coated fruits displayed a slower increase in TSS upto 28 days (in lac based coated) and 21 days (in Semperfresh $^{\mathrm{TM}}$ and vegetable wax coated fruits) followed by a steady decline.

This increasing trend of TSS with advancement of storage might be due to hydrolysis of starch to simple sugars. In the later stages of storage period, owing to the high respiration the sugars got utilized and resulted in a subsequent decrease in TSS, the decrease being more prominent in control (water dipped) fruits treated after transportation. Similar trends have been reported by Baritelle et al., (2001). Moreover, lac based edible coating was more effective in maintaining the soluble solids content during storage because of the least gas permeability of coating that decreased the respiration rate and inhibited the overall metabolic activities of plum fruits. The results are in accordance with that reported by Zhou et al., (2007) in pears wherein compared with the control, Semperfresh $^{\mathrm{TM}}$ and carboxymethyl chitosan coated fruits, the shellac coated pears retained higher total soluble solids.

Observations recorded for change in titratable acidity (TA) revealed a declining trend during storage, in both coated and control fruits (Table 2) with the decline being pronounced in case of control (water dipped) fruits as compared to coated fruits. Surface coatings apparently slowed down the reduction in acidity as compared to control (water dipped) having higher acidity retention. At the end of storage of 35 days, amongst the on-farm coated fruits, lac based and Semperfresh ${ }^{\mathrm{TM}}$ were able to retain significantly higher titratable acidity ( 95 and 93\%, respectively) as compared to vegetable wax coated fruits $(\sim 74 \%)$. Reduction in titratable acidity is typical during postharvest storage of stone fruits such as plum, attributed to the use of organic acids as substrates for the respiratory metabolism in detached fruits (Valero and 
Serrano, 2010; Díaz-Mula et al., 2012). As is the case in the present study, Valero et al., (2013) and Martinez-Romero et al., (2006) have also showed more retention of titratable acidity in alginate coated plums and aloe vera coated sweet cherry.

With regard to treatment site, it was observed that on-farm treated fruits showed a gradual reduction of titratable acidity as compared to fruits treated in the laboratory after transportation. This may be due to the protective effect of the coatings and the reduced senescence process during transportation. Earlier, Valero et al., (2013) did not find any significant effect of edible coatings on acidity losses in four cultivars of plum stored at $2^{\circ} \mathrm{C}$.

\section{Total phenol and ascorbic acid}

The 'Santa Rosa' plums studied in the present study showed an increase in total phenols initially followed by a gradual decline, the decline being more pronounced in control (water dipped) fruits. While all the coatings led to higher retention of total phenols, lac based coating was found to be the best followed by Semperfresh ${ }^{\mathrm{TM}}$ and vegetable wax coating. While all the coatings led to higher retention of total phenols, lac based and Semperfresh ${ }^{\mathrm{TM}}$ proved to be better than the vegetable wax coating (Table 3 ). This can be attributed to the delay of fruit senescence in coated fruits. There was inhibition of the ripening process because of application of coating before transportation that resulted in lower total phenols in on-farm treated samples as compared to fruits treated after transportation. Sanchez-Gonzalez et al., (2011) had earlier reported the same trend in chitosan coated grape samples.

Although a continuous decline in ascorbic acid of plum fruit throughout the storage period was observed, higher retention of vitamin $\mathrm{C}$ in coated fruits as compared to control (water dipped) fruits was observed, maximum $(\sim 85 \%)$ being in fruits coated with lac based on the farm (Table 4).

Ascorbic acid in fruits is primarily regulated by the phenoloxidase and ascorbic acid oxidase enzymes whose activities are influenced by the storage temperature and the oxygen content in the storage condition. This inhibition of ascorbic acid loss in treated plums may be due to the lower oxygen permeability of the edible coatings which might have lowered the activity of the these enzymes and retard the oxidation of ascorbic acid. Similar observations have been reported by Ayranci and Tunc (2004), Yaman and Bayoundurlc (2002) and Zhou et al., (2008).

\section{PME activity}

During the investigation we found that PME activity increased progressively with the progress in storage period irrespective of the treatment (Figure 1). Generally, the pectin methylesterase (PME) activity was significantly higher for untreated fruits with mean values of $0.174 \mu \mathrm{mol} / \mathrm{min} / \mathrm{g} F W$, respectively for on-farm treated fruits and $0.178 \mu \mathrm{mol} / \mathrm{min} / \mathrm{g} \mathrm{FW}$ for fruits treated after transportation. It was recorded that the lowest PME activity for lac based treated plums for both treatment sites. All coating treatments led to about $82-86 \%$ reduction in pectin methylesterase (PME) activity over control fruits.

The coatings form a physical barrier around the plum which leads to depletion of $\mathrm{O}_{2}$ and finally retarded the PME activity. Our results were confirmed with the study of Khan and Singh (2004, 2007). On-farm treated fruits showed comparatively less pectin methylesterase (PME) activity due to inhibition of enzyme activity at earlier stages of treatment as also in case of low temperature stored fruits. 
Table.1 Effect of application of edible coatings on total soluble solids $\left({ }^{\circ} \mathrm{B}\right)$ in plum cv. 'Santa Rosa' stored under low temperature (2 \pm $1^{\circ} \mathrm{C}$ ) conditions

\begin{tabular}{|c|c|c|c|c|c|c|c|c|c|c|c|c|c|c|}
\hline \multirow[t]{3}{*}{ Treatments } & \multicolumn{7}{|c|}{ On-farm application } & \multicolumn{7}{|c|}{ Off-farm application } \\
\hline & \multicolumn{14}{|c|}{ Storage days } \\
\hline & $\mathbf{0}$ & 7 & 14 & 21 & 28 & 35 & Mean & $\mathbf{0}$ & 7 & 14 & 21 & 28 & 35 & Mean \\
\hline Control & $\begin{array}{r}12.46 \\
\mathrm{a}\end{array}$ & $\begin{array}{r}12.86 \\
\mathrm{a}\end{array}$ & $\begin{array}{r}13.23 \\
\mathrm{a}\end{array}$ & $\begin{array}{r}13.73 \\
\mathrm{a}\end{array}$ & 13.00 & $\begin{array}{r}10.13 \\
\mathrm{a}\end{array}$ & $12.57^{\mathrm{a}}$ & $12.30_{\mathrm{d}}^{\mathrm{bc}}$ & $12.56^{\mathrm{ba}}$ & $13.23^{\mathrm{a}}$ & $13.36^{\mathrm{igh}}$ & $13.00^{\mathrm{jk}}$ & $10.63^{1}$ & $12.51^{\mathrm{c}}$ \\
\hline $\begin{array}{l}\text { Vegetable } \\
\text { wax }\end{array}$ & $\begin{array}{r}14.00 \\
\mathrm{a}\end{array}$ & $\begin{array}{r}15.26 \\
\mathrm{a}\end{array}$ & $\begin{array}{r}15.70 \\
\mathrm{a}\end{array}$ & $\begin{array}{r}12.40 \\
\mathrm{a}\end{array}$ & $\begin{array}{r}11.70 \\
\mathrm{a}\end{array}$ & $9.60^{\mathrm{a}}$ & $13.11^{\mathrm{a}}$ & $14.03^{\mathrm{igh}}$ & $14.36^{\mathrm{fgh}}$ & $15.23^{\text {fed }}$ & $12.30_{\mathrm{d}}^{\mathrm{fec}}$ & $11.33^{\mathrm{feg}}$ & $10.03^{\mathrm{lk}}$ & $12.88^{\mathrm{b}}$ \\
\hline Lac & $\begin{array}{r}12.03 \\
\mathrm{a}\end{array}$ & $\begin{array}{r}13.63 \\
\mathrm{a}\end{array}$ & $\begin{array}{r}14.33 \\
\mathrm{a}\end{array}$ & $\begin{array}{r}14.56 \\
\mathrm{a}\end{array}$ & 14.76 & $\begin{array}{r}12.13 \\
\mathrm{a}\end{array}$ & $13.57^{\mathrm{a}}$ & $12.06^{\mathrm{ijh}}$ & $13.60^{\text {bec }}$ & $14.16^{\mathrm{bc}}$ & $14.30^{\mathrm{b}}$ & $14.46^{\mathrm{ba}}$ & $\begin{array}{r}11.86^{\mathrm{ij}} \\
h\end{array}$ & $13.41^{\mathrm{a}}$ \\
\hline Semperfresh $_{\mathrm{M}}^{\mathrm{T}}$ & $\begin{array}{r}11.93 \\
\mathrm{a}\end{array}$ & $\begin{array}{r}13.60 \\
\mathrm{a}\end{array}$ & $\begin{array}{r}13.86 \\
\mathrm{a}\end{array}$ & $\begin{array}{r}14.05 \\
\mathrm{a}\end{array}$ & $\begin{array}{r}13.52 \\
\mathrm{a}\end{array}$ & $\begin{array}{r}12.00 \\
\mathrm{a}\end{array}$ & $13.16^{\mathrm{a}}$ & $\begin{array}{r}12.13^{\text {igj }} \\
h\end{array}$ & $\begin{array}{r}13.60^{\text {bec }} \\
\text { d }\end{array}$ & $\begin{array}{r}13.60^{\text {bec }} \\
\text { d }\end{array}$ & $14.05^{\mathrm{bcd}}$ & $13.35^{\mathrm{fec}}$ & $11.63^{\mathrm{ij}}$ & $13.06^{\mathrm{b}}$ \\
\hline Mean & 12.60 & $\begin{array}{r}13.84 \\
\mathrm{a}\end{array}$ & $\begin{array}{r}14.28 \\
\mathrm{a}\end{array}$ & $\begin{array}{r}13.68 \\
\mathrm{a}\end{array}$ & $\begin{array}{r}21.99 \\
\mathrm{a}\end{array}$ & $\begin{array}{r}10.96 \\
\mathrm{a}\end{array}$ & & $12.63^{\mathrm{d}}$ & $13.53^{\mathrm{b}}$ & $14.06^{\mathrm{a}}$ & $13.50^{\mathrm{b}}$ & $13.04^{\mathrm{c}}$ & $11.04^{\mathrm{e}}$ & \\
\hline
\end{tabular}

Means with same superscript are not significantly different.

Table.2 Effect of application of edible coatings on titratable acidity (\%) in plum cv. 'Santa Rosa' stored under low temperature $(2 \pm$ $1^{\circ} \mathrm{C}$ ) conditions

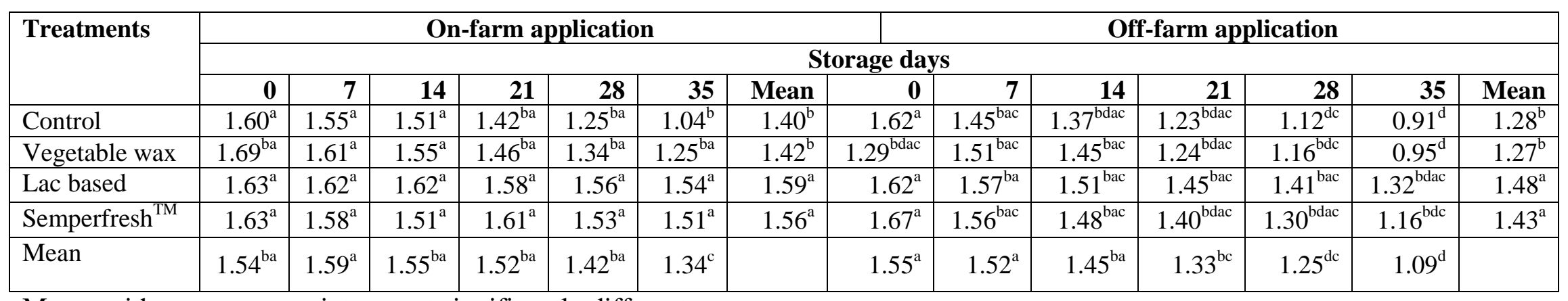

Means with same superscript are not significantly different. 
Table.3 Effect of application of edible coatings on total phenols $(\mathrm{mg} / 100 \mathrm{~g})$ in plum cv. 'Santa Rosa' stored under low temperature (2 $\pm 1^{\circ} \mathrm{C}$ ) conditions

\begin{tabular}{|c|c|c|c|c|c|c|c|c|c|c|c|c|c|c|}
\hline \multirow[t]{3}{*}{ Treatments } & \multicolumn{7}{|c|}{ On-farm application } & \multicolumn{7}{|c|}{ Off-farm application } \\
\hline & \multicolumn{14}{|c|}{ Storage days } \\
\hline & $\mathbf{0}$ & 7 & 14 & 21 & 28 & 35 & Mean & $\mathbf{0}$ & 7 & 14 & 21 & 28 & 35 & Mean \\
\hline Control & $\begin{array}{r}152.0 \\
1^{\mathrm{h}}\end{array}$ & $\begin{array}{r}165.2 \\
5^{\mathrm{g}}\end{array}$ & $\begin{array}{r}220.1 \\
4^{\mathrm{a}}\end{array}$ & $\begin{array}{r}180.2 \\
5^{\mathrm{f}}\end{array}$ & $\begin{array}{r}145.2 \\
5^{i}\end{array}$ & $\begin{array}{r}135.4 \\
7^{j}\end{array}$ & $\begin{array}{r}166.3 \\
9^{\mathrm{d}}\end{array}$ & $\begin{array}{r}150.4 \\
5^{\mathrm{i}}\end{array}$ & $\begin{array}{r}160.2 \\
5^{h}\end{array}$ & $\begin{array}{r}215.4 \\
7^{\mathrm{a}}\end{array}$ & $\begin{array}{r}175.24 \\
\mathrm{fg}\end{array}$ & $\begin{array}{r}140.2 \\
4^{j}\end{array}$ & $\begin{array}{r}130.25 \\
\mathrm{k}\end{array}$ & $\begin{array}{r}161.9 \\
8^{d}\end{array}$ \\
\hline $\begin{array}{l}\text { Vegetable } \\
\text { wax }\end{array}$ & $\begin{array}{r}152.1 \\
6^{h}\end{array}$ & $\begin{array}{r}164.5 \\
2^{\mathrm{g}}\end{array}$ & $\begin{array}{r}219.2 \\
5^{\mathrm{a}}\end{array}$ & $\begin{array}{r}190.2 \\
5^{\mathrm{d}}\end{array}$ & $\begin{array}{r}185.2 \\
5^{\mathrm{e}}\end{array}$ & $\begin{array}{r}179.6 \\
5^{\mathrm{f}}\end{array}$ & $\begin{array}{r}181.8 \\
4^{\mathrm{c}}\end{array}$ & $\begin{array}{r}150.4 \\
8 \mathrm{i}\end{array}$ & $\begin{array}{r}159.2 \\
5^{h}\end{array}$ & $\begin{array}{r}214.2 \\
5^{\mathrm{a}}\end{array}$ & $\begin{array}{r}185.47 \\
d\end{array}$ & $\begin{array}{r}180.3 \\
6^{\mathrm{e}}\end{array}$ & $\begin{array}{r}174.58 \\
\mathrm{~g}\end{array}$ & $\begin{array}{r}177.3 \\
9^{c}\end{array}$ \\
\hline Lac based & $\begin{array}{r}152.4 \\
5^{\text {h }}\end{array}$ & $\begin{array}{r}165.1 \\
4^{\mathrm{g}}\end{array}$ & $\begin{array}{r}220.1 \\
2^{\mathrm{a}}\end{array}$ & $\begin{array}{r}206.1 \\
2^{b}\end{array}$ & $\begin{array}{r}198.2 \\
3^{c}\end{array}$ & $\begin{array}{r}182.2 \\
5^{\text {fe }}\end{array}$ & $\begin{array}{r}187.3 \\
8^{\mathrm{a}}\end{array}$ & $\begin{array}{r}151.4 \\
5^{\mathrm{i}}\end{array}$ & $\begin{array}{r}160.2 \\
5^{h}\end{array}$ & $\begin{array}{r}215.2 \\
5^{\mathrm{a}}\end{array}$ & $\begin{array}{r}201.25 \\
\mathrm{~b}\end{array}$ & $\begin{array}{r}193.2 \\
5^{\mathrm{c}}\end{array}$ & $\begin{array}{r}178.25 \\
\mathrm{fe}\end{array}$ & $\begin{array}{r}183.2 \\
8^{a}\end{array}$ \\
\hline $\begin{array}{l}\text { Semperfres } \\
\mathrm{h}^{\mathrm{TM}}\end{array}$ & $\begin{array}{r}152.3 \\
4^{h}\end{array}$ & $\begin{array}{r}164.2 \\
5^{\mathrm{g}}\end{array}$ & $\begin{array}{r}219.5 \\
2^{\mathrm{a}}\end{array}$ & $\begin{array}{r}204.2 \\
5^{b}\end{array}$ & $\begin{array}{r}196.2 \\
1^{\mathrm{c}}\end{array}$ & $\begin{array}{c}180.2 \\
5^{\mathrm{f}}\end{array}$ & $\begin{array}{r}186.1 \\
3^{\mathrm{b}}\end{array}$ & $\begin{array}{r}151.4 \\
5^{\mathrm{i}}\end{array}$ & $\begin{array}{r}159.2 \\
5^{h}\end{array}$ & $\begin{array}{r}214.5 \\
8^{\mathrm{a}}\end{array}$ & $\begin{array}{r}199.25 \\
\mathrm{~b}\end{array}$ & $\begin{array}{r}191.4 \\
5^{\mathrm{c}}\end{array}$ & 175.55 & $\begin{array}{r}181.9 \\
2^{b}\end{array}$ \\
\hline Mean & $\begin{array}{r}152.2 \\
4^{\mathrm{f}}\end{array}$ & $\begin{array}{r}164.7 \\
9^{\mathrm{e}}\end{array}$ & $\begin{array}{r}219.7 \\
5^{\mathrm{a}}\end{array}$ & $\begin{array}{r}195.2 \\
1^{b}\end{array}$ & $\begin{array}{r}181.2 \\
3^{\mathrm{c}}\end{array}$ & $\begin{array}{r}169.4 \\
0^{d}\end{array}$ & & $\begin{array}{r}150.9 \\
5^{\mathrm{f}}\end{array}$ & $\begin{array}{r}159.7 \\
5^{\mathrm{e}}\end{array}$ & $\begin{array}{r}214.8 \\
8^{\mathrm{a}}\end{array}$ & $\begin{array}{r}190.30 \\
b\end{array}$ & $\begin{array}{r}176.3 \\
2^{c}\end{array}$ & 164.65 & \\
\hline
\end{tabular}

Means with same superscript are not significantly different.

Table.4 Effect of application of edible coatings on ascorbic acid content (mg/100 g) in plum cv. 'Santa Rosa' stored under low temperature $\left(2 \pm 1^{\circ} \mathrm{C}\right)$ conditions

\begin{tabular}{|c|c|c|c|c|c|c|c|c|c|c|c|c|c|c|}
\hline \multirow[t]{3}{*}{ Treatments } & \multicolumn{8}{|c|}{ On-farm application } & \multicolumn{6}{|c|}{ Off-farm application } \\
\hline & \multicolumn{14}{|c|}{ Storage days } \\
\hline & $\mathbf{0}$ & 7 & 14 & 21 & 28 & 35 & Mean & $\mathbf{0}$ & 7 & 14 & 21 & 28 & 35 & Mean \\
\hline Control & $3.14^{\mathrm{ba}}$ & $3.14^{\mathrm{ba}}$ & $2.99^{\mathrm{ba}}$ & $2.85^{\mathrm{ba}}$ & $2.70^{\mathrm{ba}}$ & $2.56^{\mathrm{a}}$ & $2.89^{\mathrm{c}}$ & $3.14^{\mathrm{a}}$ & $2.99^{\mathrm{a}}$ & $2.88^{\mathrm{a}}$ & $2.72^{\mathrm{a}}$ & $2.58^{\mathrm{a}}$ & $2.56^{\mathrm{a}}$ & $2.81^{\mathrm{c}}$ \\
\hline Vegetable wax & $3.62^{\mathrm{ba}}$ & $3.57^{\text {ba }}$ & $3.41^{\text {ba }}$ & $3.26^{\mathrm{ba}}$ & $3.14^{\text {ba }}$ & $2.99^{\mathrm{ba}}$ & $3.33^{\mathrm{bc}}$ & $3.48^{\mathrm{a}}$ & $3.76^{\mathrm{a}}$ & $3.40^{\mathrm{a}}$ & $3.18^{\mathrm{a}}$ & $3.09^{\mathrm{a}}$ & $2.85^{\mathrm{a}}$ & $3.29^{b}$ \\
\hline Lac based & $4.34^{\mathrm{a}}$ & $4.30^{\mathrm{a}}$ & $4.14^{\mathrm{ba}}$ & $4.00^{\mathrm{ba}}$ & $3.92^{\text {ba }}$ & $3.71^{\text {ba }}$ & $4.06^{\mathrm{a}}$ & $4.20^{\mathrm{a}}$ & $4.09^{\mathrm{a}}$ & $3.96^{\mathrm{a}}$ & $3.85^{\mathrm{a}}$ & $3.57^{\mathrm{a}}$ & $3.61^{\mathrm{a}}$ & $3.88^{\mathrm{a}}$ \\
\hline Semperfresh $^{\mathrm{TM}}$ & $3.90^{\mathrm{ba}}$ & $3.86^{\mathrm{ba}}$ & $3.71^{\text {ba }}$ & $3.67^{\text {ba }}$ & $3.40^{\text {ba }}$ & $3.29^{\mathrm{ba}}$ & $3.63^{\text {ba }}$ & $3.78^{\mathrm{a}}$ & $3.75^{\mathrm{a}}$ & $3.69^{\mathrm{a}}$ & $3.51^{\mathrm{a}}$ & $3.36^{\mathrm{a}}$ & $3.29^{\mathrm{a}}$ & $3.56^{\text {ba }}$ \\
\hline Mean & $3.75^{\mathrm{a}}$ & $3.72^{\mathrm{a}}$ & $3.56^{\mathrm{a}}$ & $3.44^{\mathrm{a}}$ & $3.29^{\mathrm{a}}$ & $3.14^{\mathrm{a}}$ & & $3.65^{\mathrm{a}}$ & $3.65^{\mathrm{a}}$ & $3.48^{\mathrm{a}}$ & $3.31^{\mathrm{a}}$ & $3.15^{\mathrm{a}}$ & $3.08^{\mathrm{a}}$ & \\
\hline
\end{tabular}

Means with same superscript are not significantly different. 
Fig.1 Effect of application edible coatings (A) on-farm and (B) off-farm on pectin methyl esterase activity ( $\mu \mathrm{mol}$ min-1g-1) in plum cv. 'Santa Rosa' stored under $2 \pm 1{ }^{\circ} \mathrm{C}$.Means with same superscript are not significantly different

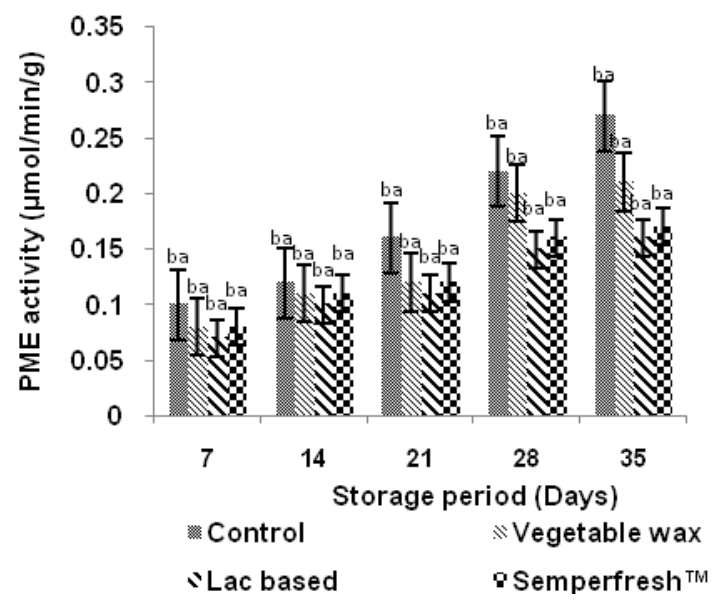

(A)

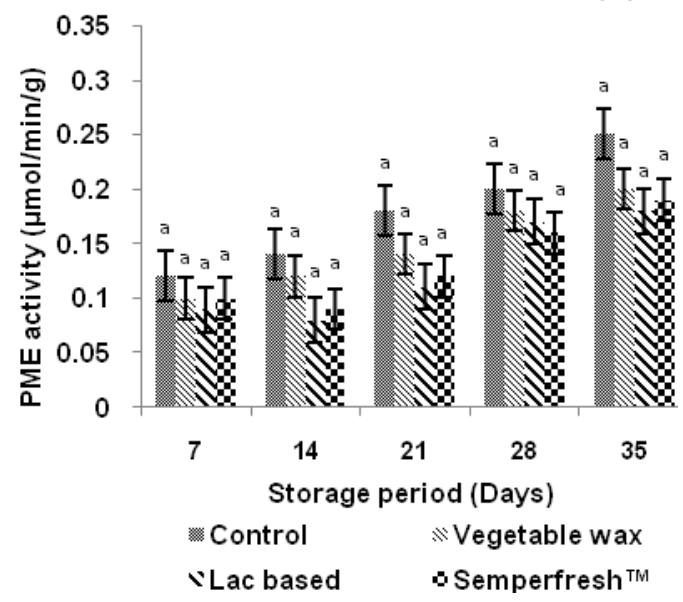

Fig.2 Effect of application edible coatings (A) on-farm and (B) off-farm on malondialdehyde content ( $\mu \mathrm{mol} \mathrm{g}-1)$ in plum cv. 'Santa Rosa' stored under $2 \pm 1^{\circ} \mathrm{C}$.Means with same superscript are not significantly different

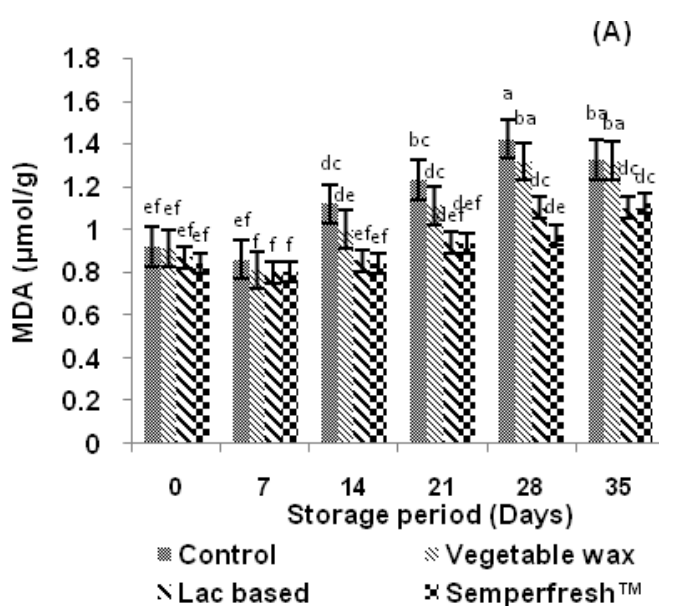

\section{Malondialdehyde content}

Malondialdehyde is mostly used as one of the indicators of cell injury due to oxidative damage as it is a product of lipid peroxidation. As shown in figure 2, a continuous rise in malondialdehyde (MDA) contents was observed in both coated and uncoated fruits. After storage of 35 days at

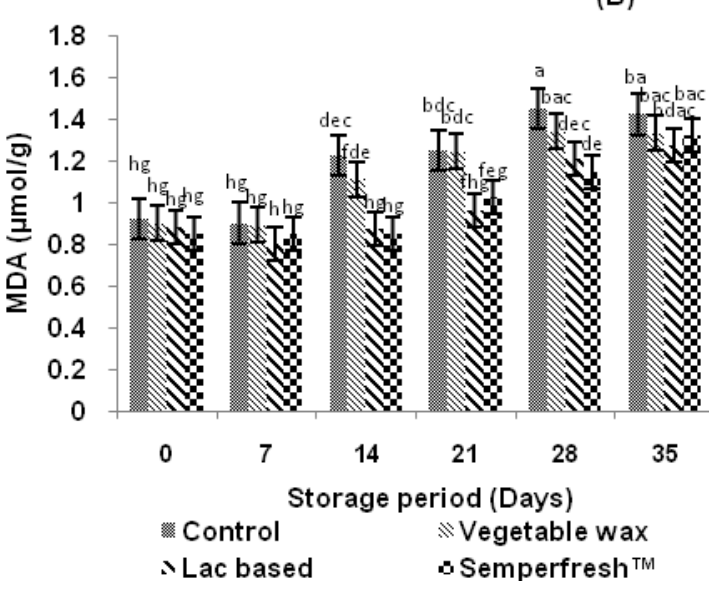

low temperature, control fruits had nearly $77 \%$ higher MDA content than lac based coated plum fruits. It was observed that the lac based coating more effective in decreasing Malondialdehyde (MDA) content with progress of storage period. Plums coated on the farm showed significantly lower mean values for malondialdehyde (MDA) as compared to off-farm coated plums. 
Continuous increase in fruit senescence associated with increase in malondialdehyde (MDA) production. Among coatings lac based was the most effective in retarding MDA production. Cold exposure also alters the structure of the membranes due to lipid peroxidation, thus leading to increase in malondialdehyde (MDA) values. Our results are in line with Eum et al., (2009) and Xing et al., (2011).

In conclusion, the results demonstrated that coatings are effective as postharvest treatments to maintain fruit quality of 'Santa Rosa' plums. The coatings evaluated in this study showed different effects on prolonging the storage life of the plums with lac based showing the most promising effects, closely followed by Semperfresh ${ }^{\mathrm{TM}}$ and vegetable wax.

In terms of storage period, the lac based and Semperfresh ${ }^{\mathrm{TM}}$ were most effective to extend the plum storage life with optimal quality by one week in $2 \pm 1^{\circ} \mathrm{C}$ stored fruits as compared to control. Lac based and Semperfresh ${ }^{\mathrm{TM}}$ coatings were able to control the fruit rotting very effectively for fruits stored at $2 \pm 1^{\circ} \mathrm{C}$ with no decay seen till end of 35 days of storage in on-farm treated fruits. Also on-farm application of these edible coatings proved to be better in preserving fruit quality.

\section{Acknowledgements}

This research was financially supported by the Division of Food Science and Postharvest Technology, Indian Agricultural Research Institute, India. Pushpendra Kumar as principal author performed analysis on all samples, interpreted data and wrote manuscript. Co-author Dr. Shruti Sethi supervised work, manuscript editing and evaluation. We are grateful to Dr. R. R. Sharma for valuable comments on this work.

\section{References}

Baldwin, E.A., Nisperos, M.O., Chen, X., Hagenmaier, R.D. 1996. Improving storage life of cut apple and potato with edible coating. Postharvest Biol. Technol., 9: 151-163.

Baritelle, A.L., Hyde, G.M., Fellman, J.K., Varith, J. 2001. Using 1-MCP to inhibit the influence of ripening on impact properties of pear and apple tissue. Postharvest Biol.Technol., 23: 153-160.

Base SAS® 9.3. 2014. Procedures Guide. Cary, NC: SAS Institute, USA.

Campos, C.A., Gerschenson, L.N., Flores, S.K. 2011. Development of edible films and coatings with antimicrobial activity. Food and Bioprocess Technol., 4: 849875.

Crisosto, C.H., Garner, D., Crisosto, G.M., Bowerman, E. 2004. Increasing "Blackam-ber" plum (Prunus salicina Lindell) consumer acceptance. Postharvest Biol. Technol., 34: 237-244.

Díaz-Mula, H.M., Martínez-Romero, D., Castillo, S., Serrano, M., Valero, D., 2011. Modified atmosphere packaging of yellow and purple plum cultivars. 1 . Effect on organoleptic quality. Postharvest Biol. Technol., 61: 103-109.

Diaz-Mula, H.D., Serrano, M., Valero, D. 2012. Alginate coatings preserve fruit quality and bioactive compounds during storage of sweet cherry fruit. Food and Bioprocess Technol., 5: 2990-2997.

Eum, H.L., Hwang, D.K., Linke, M., Lee, S.K. 2009. Influence of edible coating on quality of plum (Prunus salicina Lindl. cv. 'Sapphire'). Eur. Food Res. Technol., 29: 427-434.

Olivas, G.I., Dávila-Avina, J.E., Salas-Salazar, N.A., Molina, F.J. 2008. Use of edible coatings to preserve the quality of fruits and vegetables during storage. Stewart Postharvest Rev., 3: 6.

Ranganna, S. 1999. Handbook of Analysis and 
Quality Control for Fruits and Vegetable Products $3^{\text {rd }}$ edition. Tata McGraw-Hill Publishing Company Ltd.

Sánchez-González, L., Pastor, C., Vargas, M., Chiralt, A., González-Martínez, C. 2011. Effect of hydroxypropylmethylcellulose and chitosan coatings with and without bergamot essential oil on quality and safety of cold-stored grapes. Postharvest Biol. Technol., 60: 57-63.

Serrano, M., Díaz-Mula, H.M., Zapata, P.J., Castillo, S., Guillén, F., MartínezRomero, D., Valverde, J.M., Valero, D. 2009. Maturity stage at harvest determines the fruit quality and antioxidant potential alter storage of sweet cherry cultivars. J. Agric. Fd. Chem., 57: 3240-3246.

Truter, A.G., Combrink, J.C., VanMollendorff, L.J. 1994. Controlled atmosphere storage of plums. Deciduous Fruit Grower, 44: 373-375.

Valero, D., Serrano, M. 2010. Postharvest biology and technology for preserving fruit quality. CRC-Taylor \& Francis, Boca Raton, USA.

Valero, D., Mula-diaz, H.M., Zapata, P.J. 2013. Effect of alginate edible coating on preserving fruit quality in four plum cultivars during postharvest storage. Postharvest Biol. Technol., 77: 1-6.

Wrolstad, R.E., Durst, R.W., Lee, J. 2005. Tracking colour and pigment changes in anthocyanin products. Trends in Food Sci. Technol., 16: 423-428.

Yaman, O., Bayoundurlc, L. 2002. Effect of an edible coating and cold storage on shelf life and quality of cherries. Lebensm-Wiss-U-Technol., 35: 146-150.

Zhou, R., Mo, Y., Li, Y. 2008. Quality and internal characteristics of huanghua pears (Pyrus pyrifolia Nakai, cv. Huanhhua) treated with different kinds of coating during storage. Postharvest Biol. Technol., 49: 171-179.

\section{How to cite this article:}

Pushpendra Kumar, Shruti Sethi and Sharma, R.R. 2017. Combined Effect of Edible Coatings and Low Temperature on Plum Fruit Quality. Int.J.Curr.Microbiol.App.Sci. 6(7): 4210-4218. doi: https://doi.org/10.20546/ijcmas.2017.607.436 